\title{
Therapeutic Approach for Chikungunya Infection
}

\author{
Markovnikov Reagan C1, Prasad VN1, Gopikumar MS² and Honnavar P3* \\ ${ }^{1}$ Student, Department of Pharmacology, Xavier University School of Medicine, Aruba \\ 2 Department of Physiology, Xavier University School of Medicine, Aruba \\ ${ }^{3}$ Department of Microbiology \& Immunology, Xavier University School of Medicine, Aruba
}

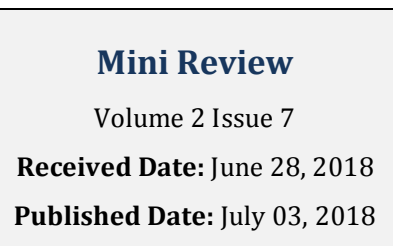

*Corresponding author: Dr. Prasanna Honnavar, Dept of Microbiology \& Immunology, Xavier University School of Medicine, Aruba, Tel: +297-588-7766, Email: prasannna1@gmail.com

\begin{abstract}
Chikungunya is endemic to sub-Saharan Africa and South and East Asia, in recent years, it has been expanding its horizon due to increasing international travel. Patients present with fever, headache, rash and severe symmetrical polyarthralgia. More than a million Chikungunya viral cases are reported annually, which can hamper individual's quality of life and most of the time they undergo long-term rheumatologic complaints. Despite the copious amount of extensive and prolonged research that has been conducted by researchers, an effective novel and potent anti-Chikungunya drug has yet to be developed. This review provides an overview on currently available treatments, and recent findings and progress in the development of major therapeutic strategies that are being evaluated as treatments for Chikungunya virus induced disease.
\end{abstract}

Keywords: Chikungunya; Infection

\section{Introduction}

Along with the likes of other ailments such as Herpes Simplex Virus (HSV), Ebola virus, and Human Immunodeficiency Virus (HIV), Chikungunya remains one of the numerous infections that is deemed to be generally incurable [1]. This convoluted disease was originally discovered and examined in the United Republic of Tanzania during 1952 [2]. Chikungunya virus is a mosquito transmitted (female Aedes aegypti and albopictus) alpha virus of the Togaviridae family. Although it is endemic to sub-Saharan Africa and South and East Asia, in recent years, it has been expanding its horizon due to increasing international travel $[3,4]$. In addition, globalization and climate changes are aiding the mosquitoes to spread to new geographic locations [5].
Chikungunya viral disease affects all age groups. After the typical incubation period of 4-7 days patients present with fever, headache, rash and severe symmetrical polyarthralgia [6,7]. Tarsal joints activities leads to extreme pain. Individuals with pre-existing underlying conditions, elderly and neonates are susceptible to Chikungunya viral disease with fatal outcome [8-10]. In terms of severity, Chikungunya is one of the milder and less harmful virus-associated ailments (compared to other viral-associated diseases, such as HSV or HIV) that most affected individuals are generally able to overcome without a significant degree of difficulty [2]. Even with the lack of an established medical product that could be used as a means to treat and cure the Chikungunya disease, the probability of a fatality resulting from such a trifling illness is generally low in the majority of cases [1]. 
More than a million Chikungunya viral cases are reported annually, which can hamper individual's quality of life and most of the time they undergo long-term rheumatologic complaints [11]. Despite the copious amount of extensive and prolonged research that has been conducted by researchers, an effective novel and potent anti-Chikungunya drug has yet to be developed [2]. The cases are spreading beyond endemic areas due to poor vector controls, elevating global temperatures and a lack of licensed vaccines or therapeutics. This review provides an overview on recent findings and progress in the development of major therapeutic strategies that are being evaluated as treatments for Chikungunya virus induced disease.

\section{Current Treatments}

Non-steroid anti-inflammatory drugs (NSAIDs), are the drug of choice for management of arthritis/arthralgia in addition to fluid intake to prevent dehydration. The other drugs such as aspirin may lead to bleeding and corticosteroids will cause immunosuppression. Diseasemodifying anti-rheumatic drugs (DMARDs) such as sulfasalazine, methotrexate and hydroxychloroquine have been used in patients with chronic Chikungunya viral disease and those exhibit limited response to NSAIDs $[12,13]$.

\section{Treatment of Acute Chikungunya Disease}

Treatment of acute Chikungunya virus disease can be broadly classified as virus-targeted (to reduce viral load) and host-targeted therapies (inhibit host cellular response or reduce host inflammatory response).

\section{Virus-targeted antivirals}

Ribavirin, one of the earliest broad-spectrum candidate antivirals in combination with interferon-alpha (IFN- $\alpha$ ), which received FDA approval for the treatment of chronic hepatitis $C$ virus and respiratory syncytial virus in infants, has been shown to reduce Chikungunya virus replication both in vitro and in a small clinical study [1417]. Ribavirin is a synthetic guanosine nucleoside analogue that can inhibit the cellular inosine monophosphate dehydrogenase enzyme leading to depletion of cellular pools of GTP [18]. Mycophenolic acid has similar molecular mechanism as that of ribavirin and in vitro studies have shown anti-Chikungunya virus activity [19]. It is being used as an immunosuppressant in organ transplantations.

Other antiviral agents like Favipiravir (T-705 and with its de-fluorinated analogue T-1105) and Arbidol approved in Japan, Russia and China for the treatment against influenza virus inhibited Chikungunya virus replication in vitro [20-22]. Similar broad-spectrum drug suramin (licensed for treatment against trypanosomiasis have shown anti-Chikungunya virus effect in vitro [23]. The efficacy of these drugs needs to be verified using in vivo models of Chikungunya virus infection.

Harringtonine (a plant alkaloid compound) and its methylated derivative homoharringtonine (omacetaxine mepesuccinate), have shown anti-Chikungunya replication in vitro [24]. This compound is believed to compete with tRNAs and stop translation. In addition it can halt the synthesis of viral structural E2 protein and non-structural protein nsP3. This drug is being used for the treatment of chronic myelogenous leukemia [24-26].

An antimetabolite, 6-azauridine, which reduces the UTP levels and inhibit the replication of several DNA and RNA viruses has shown anti-in vitro Chikungunya virus activity. 6-azauridine (a uridine nucleoside analogue) inhibits the enzyme orotidine monophosphate decarboxylase leading to reduced level of pyrimidine $[16,28,29]$.

Similarly, $\beta$-D-N4-hydroxycytidine (NHC- nucleoside analogue), was found to selectively inhibit Chikungunya virus replication in vitro. It has been previously shown to inhibit hepatitis C virus replication [30]. A number of novel antiviral agents have been found to selectively target nsP1 and nsP2, leading to inhibition of in vitro Chikungunya virus replication [31-33].

Several broad-spectrum antiviral compounds have passed clinical trials in humans for other conditions and have been shown anti-Chikungunya virus in vitro activity. Further future in vivo research is warranted before considering their use in a clinical setting and makes them available during Chikungunya virus epidemic.

\section{Antibody therapies}

Neutralizing antibodies have shown promising results as a prophylactic and therapeutic treatment strategy in animal models of Chikungunya virus infection [34,35]. Human convalescent-phase plasma passive transfer to neonatal and IFNAR-/- (IFN receptor knockout mice) has protected against Chikungunya virus disease [35]. A similar result has been illustrated with nonhuman primate polyclonal antibodies [34]. Moreover in vitro and mice model studies have shown viral neutralization by human and murine monoclonal antibodies (mAbs). These mAbs may be either combinatorial-mAbs or mAbs directed at the E1 and E2 domains [36-41]. 
Additionally, anti-Chikungunya virus mAbs used as prophylactic treatment for RAG1-/- mice reduced viral titers in muscle tissue and sera [42]. Similarly, rapid viral clearance and low joint inflammation was observed in infected rhesus macaques after treatment with mAbSVIR001 [43].

The above said mAb and polyclonal antibodies have shown promising results in the early phase of infection and can be used in humans at higher risk. However, Chikungunya virus-infected patients usually present several days after the onset of symptoms. To overcome the inflammatory process in such condition a combination therapy with $4 \mathrm{~N} 12 \mathrm{mAb}$ and abatacept (T-cell costimulator inhibitor) was found to be very effective [44].

Anti-Chikungunya virus antibody therapies could be recommended for high risk populations, such as Chikungunya virus infected pregnant women during the late stage of pregnancy, to protect the child from Chikungunya virus induced neurologic disease, AntiChikungunya virus antibody might be administered to immunosuppressed individuals, known virus exposed laboratory personal or patients with known underlying conditions like cardiac failure, diabetes mellitus, and chronic obstructive pulmonary disease [44-47].

Prophylactic approaches would be recommended for patients living in Chikungunya virus-endemic regions. However, due to high costs for booster dose and logistical concerns about antibody delivery, its role during Chikungunya virus outbreaks remains unclear. Additionally these antibodies have short serum half-life, hypersensitive and high production costs. Future research is warranted to produce long term protecting, costeffective and easily accessible antibodies.

\section{Host-Targeted Antivirals}

In vitro studies have shown that Chloroquine (antimalarial drug) prevents the entry of Chikungunya virus inside the cell by increasing the endosomal $\mathrm{pH}$ [48]. However, contrasting results have been obtained from in vitro and clinical trials. Human clinical trials have shown ineffective and even exaggerated arthralgia [49,50]. As host inflammatory response is the major key factor for the Chikungunya virus induced arthritides, researchers have tried host inflammatory response inhibitors such as Bindarit, as a treatment alternative. However, similar to Chloroquine conflicting results have been shown in different rodent model studies. Future studies are warranted with nonhuman primate models of Chikungunya virus infection [51-54].

\section{Therapies for Chronic Chikungunya Disease}

Most of the patients suffer from chronic arthralgia even after years of post-infection. The pathogenesis of chronic Chikungunya virus-associated arthralgia is poorly understood compared to acute Chikungunya virus infection. Currently treatment options are NSAIDs and antirheumatic drugs (methotrexate) [13,39]. There is lot of lacunae in better understanding of host factors and the virus in chronic disease pathogenesis $[13,39]$.

\section{Other therapeutic approaches}

In vitro and animal model studies have also used short hairpin or small interfering RNA elements as a therapeutic approach to restrict viral replication [54,55]. However, as this approach is entirely dependent on Chikungunya virus strains, viral mutation can significantly reduce the effectiveness. In future these limitations can be overcome by using multiple interfering elements.

\section{Future Directions}

Till date precise cellular mechanism of Chikungunya virus infection is not known. Although we know about the structure of virus and its role in pathogenesis, we know less about human target cell receptors [56,57]. Even though we know about the acute state of disease, chronic disease mechanism is yet to be delineated. Majority of Chikungunya virus pathogenesis studies have focused on in vitro and animal models. Currently 3D scaffolds and models of the GI tract, brain, kidney, lung, liver, and skin have shown promising results in studying infectious disease, as it is composed of multiple cell types established in a particular organ [58]. Similarly, 3D models can be utilized for understanding the molecular level pathogenesis in potential target organ systems such as brain, bone, cartilage, joints.

\section{Conclusion}

In conclusion, this updated mini-review summarizes the currently available treatment, current status of research progress and future directions for development of safe, affordable and effective therapeutics for Chikungunya virus infection. 


\begin{tabular}{|c|c|c|c|}
\hline Therapeutic Agents & $\begin{array}{l}\text { Used for the } \\
\text { Treatment of }\end{array}$ & $\begin{array}{c}\text { Experimental Models } \\
\text { used to Study } \\
\text { Chikungunya Virus } \\
\end{array}$ & Mechanism of Action \\
\hline \multicolumn{4}{|c|}{ Current Treatment } \\
\hline $\begin{array}{l}\text { Non-steroid anti-inflammatory } \\
\text { drugs (NSAID) }\end{array}$ & $\begin{array}{c}\text { Acute } \\
\text { arthritis/arthralgia }\end{array}$ & - & $\begin{array}{c}\text { Inhibit the activity of } \\
\text { cyclooxygenase enzymes } \\
\text { (COX-1 and/or COX-2) } \\
\text { leading to reduced } \\
\text { prostaglandins } \\
\end{array}$ \\
\hline Fluid intake & $\begin{array}{c}\text { Acute } \\
\text { arthritis/arthralgia }\end{array}$ & - & 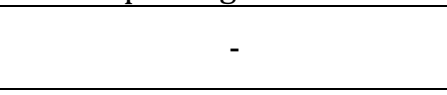 \\
\hline $\begin{array}{c}\text { Disease-modifying anti-rheumatic } \\
\text { drugs (DMARDS's) }\end{array}$ & $\begin{array}{l}\text { Chronic Chikungunya } \\
\text { viral disease }\end{array}$ & - & Several \\
\hline \multicolumn{4}{|c|}{ Treatment of Acute Chikungunya Virus Disease } \\
\hline \multicolumn{4}{|c|}{ A1. Virus-Targeted Antivirals } \\
\hline Ribavirin + IFN- $\alpha$ & $\begin{array}{l}\text { Chronic hepatitis } \mathrm{C} \\
\text { virus and respiratory } \\
\text { syncytial virus }\end{array}$ & $\begin{array}{l}\text { in vitro and in a small } \\
\text { clinical study }\end{array}$ & $\begin{array}{c}\text { Inhibit the cellular inosine } \\
\text { monophosphate } \\
\text { dehydrogenase enzyme } \\
\text { leading to depletion of } \\
\text { cellular pools of GTP }\end{array}$ \\
\hline $\begin{array}{l}\text { Favipiravir (T-705 and with its } \\
\text { de-fluorinated analogue T-1105) }\end{array}$ & $\begin{array}{l}\text { Influenza virus used in } \\
\text { Japan }\end{array}$ & in vitro & $\begin{array}{c}\text { Inhibition of viral RNA- } \\
\text { dependent RNA polymerase }\end{array}$ \\
\hline Arbidol & $\begin{array}{l}\text { Influenza virus used in } \\
\text { Russia and China }\end{array}$ & in vitro & $\begin{array}{c}\text { Prevents contact between } \\
\text { the virus and target host } \\
\text { cells }\end{array}$ \\
\hline Suramin & $\begin{array}{c}\text { Treatment against } \\
\text { trypanosomiasis }\end{array}$ & in vitro & $\begin{array}{l}\text { Combines glycolytic enzymes } \\
\text { to inhibit energy metabolism }\end{array}$ \\
\hline Mycophenolic acid & $\begin{array}{l}\text { Immunosuppressant in } \\
\text { organ transplantations }\end{array}$ & in vitro & Similar to ribavirin \\
\hline $\begin{array}{c}\text { Harringtonine and } \\
\text { homoharringtonine (omacetaxine } \\
\text { mepesuccinate) }\end{array}$ & $\begin{array}{l}\text { Chronic myelogenous } \\
\text { leukemia }\end{array}$ & in vitro & $\begin{array}{l}\text { Compete with tRNAs and } \\
\text { stop translation. halt the } \\
\text { synthesis of viral structural } \\
\text { E2 protein and non- } \\
\text { structural protein nsP3 }\end{array}$ \\
\hline 6-azauridine & An antimetabolite & in vitro & $\begin{array}{l}\text { Reduces the UTP levels and } \\
\text { inhibit the replication of } \\
\text { several DNA and RNA } \\
\text { viruses. Inhibits the enzyme } \\
\text { orotidine monophosphate } \\
\text { decarboxylase leading to } \\
\text { reduced level of pyrimidine }\end{array}$ \\
\hline$\beta$-D-N4-hydroxycytidine & $\begin{array}{l}\text { Inhibit hepatitis C } \\
\text { virus replication }\end{array}$ & in vitro & NHC- nucleoside analogue \\
\hline \multicolumn{4}{|c|}{ Antibody Therapies } \\
\hline $\begin{array}{l}\text { Human convalescent-phase } \\
\text { plasma }\end{array}$ & - & $\begin{array}{l}\text { Neonatal and } \\
\text { IFNAR-/- (IFN } \\
\text { receptor knockout } \\
\text { mice) }\end{array}$ & - \\
\hline $\begin{array}{c}\text { Nonhuman primate polyclonal } \\
\text { antibodies }\end{array}$ & - & $\begin{array}{l}\text { Neonatal and } \\
\text { IFNAR-/- mice }\end{array}$ & - \\
\hline $\begin{array}{c}\text { Human and murine monoclonal } \\
\text { antibodies (mAbs). }\end{array}$ & - & $\begin{array}{l}\text { in vitro and mice } \\
\text { model }\end{array}$ & - \\
\hline
\end{tabular}




\begin{tabular}{|c|c|c|c|}
\hline $\begin{array}{l}\text { Combinatorial-mAb or mAbs } \\
\text { directed at the E1 and E2 domains }\end{array}$ & & & \\
\hline $\begin{array}{l}\text { Anti-Chikungunya virus mAbs } \\
\text { used as prophylactic treatment }\end{array}$ & - & RAG1-/- mice & - \\
\hline mAb-SVIR001 & - & Rhesus macaques & - \\
\hline $\begin{array}{l}\text { Combination therapy with 4N12 } \\
\text { mAb and abatacept (T-cell co- } \\
\text { stimulator inhibitor) }\end{array}$ & $\begin{array}{l}\text { Chronic Chikungunya } \\
\text { viral disease }\end{array}$ & 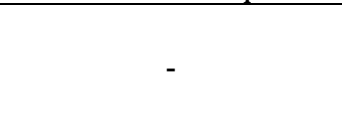 & - \\
\hline \multicolumn{4}{|c|}{ A2. Host-Targeted Antivirals } \\
\hline $\begin{array}{l}\text { Chloroquine (contrasting results } \\
\text { have been obtained from in vitro } \\
\text { and clinical trials) }\end{array}$ & Antimalarial drug & $\begin{array}{l}\text { In vitro and human } \\
\text { clinical trials }\end{array}$ & Increasing the endosomal $\mathrm{pH}$ \\
\hline Bindarit(conflicting results) & $\begin{array}{l}\text { Host inflammatory } \\
\text { response inhibitors }\end{array}$ & Rodent model studies & Inhibition of NFKB pathway \\
\hline \multicolumn{4}{|c|}{ Therapies for Chronic Chikungunya Virus Disease } \\
\hline $\begin{array}{l}\text { NSAIDs and antirheumatic drugs } \\
\text { (methotrexate) }\end{array}$ & - & - & - \\
\hline \multicolumn{4}{|c|}{ Others } \\
\hline $\begin{array}{l}\text { Short hairpin or small interfering } \\
\text { RNA elements }\end{array}$ & - & $\begin{array}{l}\text { In vitro and animal } \\
\text { models }\end{array}$ & - \\
\hline
\end{tabular}

Table: Therapeutic approach for Chikungunya infection.

\section{Acknowledgment}

We duly acknowledge Ms. Kendra Parson, the chief librarian, XUSOM for language editing.

\section{References}

1. Wauquier N, Becquart P, Nkoghe D, Padilla C, NdjoyiMbiguino A, et al. (2010) The acute phase of Chikungunya virus infection in humans is associated with strong innate immunity and T CD8 cell activation. The Journal of Infectious Diseases 204(1): 115-123.

2. Mahendradas P, Avadhani K, Shetty R (2013) Chikungunya and the eye: a review. Journal of Ophthalmic Inflammation and Infection 3(1): 35.

3. Tomasello D, Schlagenhauf P (2013) Chikungunya and dengue autochthonous cases in Europe, 20072012. Travel Med Infect Dis 11(5): 274-284.

4. Enserink M (2007) Infectious diseases. Chikungunya: no longer a third world disease. Science 318(5858): 1860-1861.

5. Reiter P, Fontenille D, Paupy C (2006) Aedes albopictus as an epidemic vector of Chikungunya virus: another emerging problem? Lancet Infect Dis 6(8): 463-464.
6. Soumahoro MK, Gérardin P, Boëlle PY, Perrau J, Fianu A, et al. (2009) Impact of Chikungunya virus infection on health status and quality of life: a retrospective cohort study. PLoS One 4(11): e7800.

7. Burt FJ, Chen W, Miner JJ, Lenschow DJ, Merits A, et al. (2017) Chikungunya virus: an update on the biology and pathogenesis of this emerging pathogen. Lancet Infect Dis 17(4): e107-e117.

8. Josseran L, Paquet C, Zehgnoun A, Caillere N, Le Tertre A, et al. (2006) Chikungunya disease outbreak, Reunion Island. Emerging Infect Dis 12(12): 19941995.

9. Renault P, Solet JL, Sissoko D, Balleydier E, Larrieu S, et al. (2007) A major epidemic of Chikungunyavirus infection on Reunion Island, France, 2005-2006. Am J Trop Med Hyg 77(4): 727-731.

10. Schilte C, Staikowsky F, Couderc T, Madec Y, Carpentier F, et al. (2013) Chikungunya virusassociated longterm arthralgia: a 36-month prospective longitudinal study. PloS Negl Trop Dis 7(3): e2137.

11. Thiberville SD, Moyen N, Dupuis-Maguiraga L, Nougairede A, Gould EA, et al. (2013) Chikungunya fever: epidemiology, clinical syndrome, pathogenesis and therapy. Antiviral Res 99(3): 345-370. 


\section{Virology \& Immunology Journal}

12. Ravindran V, Alias G (2017) Efficacy of combination DMARD therapy vs. hydroxychloroquine monotherapy in chronic persistent chikungunya arthritis: a 24-week randomized controlled open label study. Clin Rheumatol 36(6): 1335-1340.

13. Ganu MA, Ganu AS (2011) Post-chikungunya chronic arthritis--our experience with DMARDs over two year follow up. J Assoc Physicians India 59: 83-86.

14. Pawlotsky JM (2014) New hepatitis C therapies: the toolbox, strategies, and challenges. Gastroenterology 146(5): 1176-1192.

15. Turner TL, Kopp BT, Paul G, Landgrave LC, Hayes D Jr, et al. (2014) Respiratory syncytial virus: current and emerging treatment options. Clinicoecon Outcomes Res 6: 217-225.

16. Briolant S, Garin D, Scaramozzino N, Jouan A, Crance JM (2004) In vitro inhibition of Chikungunya and Semliki Forest viruses replication by antiviral compounds: synergistic effect of interferon-alpha and ribavirin combination. Antiviral Res 61(2): 111-117.

17. Ravichandran R, Manian M (2008) Ribavirin therapy for Chikungunya arthritis. J Infect Dev Ctries 2(2): 140-142.

18. Graci JD, Cameron CE (2006) Mechanisms of action of ribavirin against distinct viruses. Rev Med Virol 16(1): 37-48.

19. Khan M, Dhanwani R, Patro IK, Rao PV, Parida MM (2011) Cellular IMPDH enzyme activity is a potential target for the inhibition of Chikungunya virus replication and virus induced apoptosis in cultured mammalian cells. Antiviral Res 89(1): 1-8.

20. Delang L, Segura Guerrero N, Tas A, Quérat G, Pastorino B, et al. (2014) Mutations in the Chikungunya virus non-structural proteins cause resistance to favipiravir (T-705), a broad-spectrum antiviral. J Antimicrob Chemother 69(10): 2770-2784.

21. Delogu I, Pastorino B, Baronti C, Nougairède A, Bonnet E, et al. (2011) In vitro antiviral activity of arbidol against Chikungunya virus and characteristics of a selected resistant mutant. Antiviral Res 90(3): 99-107.

22. Blaising J, Polyak SJ, Pécheur EI (2014) Arbidol as a broad-spectrum antiviral: an update. Antiviral Res 107: 84-94.
23. Albulescu IC, van Hoolwerff M, Wolters LA, Bottaro E, Nastruzzi C, et al. (2015) Suramin inhibits chikungunya virus replication through multiple mechanisms. Antiviral Res 121: 39-46.

24. Kaur P, Thiruchelvan M, Lee RC, Chen H, Chen KC, et al. (2013) Inhibition of Chikungunya virus replication by harringtonine, a novel antiviral that suppresses viral protein expression. Antimicrob Agents Chemother 57(1): 155-167.

25. Fresno M, Jimenez A, Vazquez D (1977) Inhibition of translation in eukaryotic systems by harringtonine. Eur J Biochem 72(2): 323-330.

26. Fan IJ, Han R (1979) The effect of harringtonine on the cell cycle of L-1210 cells and the bone marrow stem cells in mice. Yao Xue Xue Bao 14(8): 467-473.

27. Scholte FEM, Tas A, Martina BEE, Cordioli P, Narayanan K, et al. (2013) Characterization of synthetic Chikungunya viruses based on the consensus sequence of recent E1-226V isolates. PLoS One 8(8): e71047.

28. Pohjala L, Utt A, Varjak M, Lulla A, Merits A, et al. (2011) Inhibitors of alphavirus entry and replication identified with a stable Chikungunya replicon cell line and virus-based assays. PLoS One 6(12): e28923.

29. Ehteshami M, Tao S, Zandi K, Hsiao HM, Jiang $Y$, et al. (2017) Characterization of $\beta$-d-N $\mathrm{N}^{4}$ - Hydroxycytidine as a Novel Inhibitor of Chikungunya Virus. Antimicrob Agents Chemother 61(4): e02395-02316.

30. Bassetto M, De Burghgraeve T, Delang L, Massarotti A, Coluccia A, et al. (2013) Computer-aided identification, design and synthesis of a novel series of compounds with selective antiviral activity against chikungunya virus. Antiviral Res 98(1): 12-18.

31. Delang L, Li C, Tas A, Quérat G, Albulescu IC, et al. (2016) The viral capping enzyme nsP1: a novel target for the inhibition of chikungunya virus infection. Sci Rep 6: 31819.

32. Gigante A, Gómez-SanJuan A, Delang L, Li C, Bueno O, et al. (2017) Antiviral activity of $(1,2,3)$ triazolo $(4,5-$ d) pyrimidin-7 $(6 \mathrm{H})$-ones against chikungunya virus targeting the viral capping nsP1. Antiviral Res 144: 216-222.

33. Akahata W, Yang ZY, Andersen H, Sun S, Holdaway HA, et al. (2010) A virus-like particle vaccine for 


\section{Virology \& Immunology Journal}

epidemic Chikungunya virus protects nonhuman primates against infection. Nat Med 16(3): 334-338.

34. Couderc T, Khandoudi N, Grandadam M, Visse C, Gangneux N, et al. (2009) Prophylaxis and therapy for Chikungunya virus infection. J Infect Dis 200(4): 516523.

35. Themis Bioscience $\mathrm{GmbH}$, Assign Clinical Research $\mathrm{GmbH}, \mathrm{ABF}$ Pharmaceutical Services $\mathrm{GmbH}$, et al. (2017) Phase II Study to Evaluate Safety and Immunogenicity of a Chikungunya Vaccine. Clinical Trials.gov.

36. Warter L, Lee CY, Thiagarajan R, Grandadam M, Lebecque S, et al. (2011) Chikungunya virus envelope-specific human monoclonal antibodies with broad neutralization potency. J Immunol 186(5): 3258-3264.

37. Goh LY, Hobson Peters J, Prow NA, Gardner J, Bielefeldt Ohmann $\mathrm{H}$, et al. (2013) Neutralizing monoclonal antibodies to the E2 protein of chikungunya virus protects against disease in a mouse model. Clin Immunol 149(3): 487-497.

38. Selvarajah S, Sexton NR, Kahle KM, Fong RH, Mattia KA, et al. (2013) A neutralizing monoclonal antibody targeting the acid-sensitive region in chikungunya virus E2 protects from disease. PloS Negl Trop Dis 7: e2423.

39. Jin J, Liss NM, Chen DH, Liao M, Fox JM, et al. (2015) Neutralizing monoclonal antibodies block Chikungunya virus entry and release by targeting an epitope critical to viral pathogenesis. Cell Rep 13(11): 2553-2564.

40. Smith SA, Silva LA, Fox JM, Flyak AI, Kose N, et al. (2015) Isolation and characterization of broad and ultrapotent human monoclonal antibodies with therapeutic activity against Chikungunya virus. Cell Host Microbe 18(1): 86-95.

41. Hawman DW, Stoermer KA, Montgomery SA, Pal P, Oko L, et al. (2013) Chronic joint disease caused by persistent Chikungunya virus infection is controlled by the adaptive immune response. J Virol 87(24): 13878-13888.

42. Broeckel R, Fox JM, Haese N, Kreklywich CN, Sukulpovi-Petty S, et al. (2017) Therapeutic administration of a recombinant human monoclonal antibody reduces the severity of Chikungunya virus disease in rhesus macaques. PloS Negl Trop Dis 11(6): e0005637.

43. Miner JJ, Cook LE, Hong JP, Smith AM, Richner JM, et al. (2017) Therapy with CTLA4-Ig and an antiviral monoclonal antibody controls Chikungunya virus arthritis. Sci Transl Med 9(375): eaah3438.

44. Gérardin P, Barau G, Michault A, Bintner M, Randrianaivo $\mathrm{H}$, et al. (2008) Multidisciplinary prospective study of mother-to-child chikungunya virus infections on the island of La Réunion. PLoS Med 5(3): e60.

45. Ramful D, Carbonnier M, Pasquet M, Bouhmani B, Ghazouani J, et al. (2007) Mother-to-child transmission of Chikungunya virus infection. Pediatr Infect Dis J 26(9): 811-815.

46. Lemant J, Boisson V, Winer A, André H, Tixier F, et al. (2008) Serious acute chikungunya virus infection requiring intensive care during the Reunion Island outbreak in 2005-2006. Crit Care Med 36(9): 25362541.

47. Khan M, Santhosh SR, Tiwari M, Lakshmana Rao PV, Parida M (2010) Assessment of in vitro prophylactic and therapeutic efficacy of chloroquine against Chikungunya virus in Vero cells. J Med Virol 82(5): 817- 824.

48. Chopra A, Saluja M, Venugopalan A (2014) Effectiveness of chloroquine and inflammatory cytokine response in patients with early persistent musculoskeletal pain and arthritis following chikungunya virus infection. Arthritis Rheumatol 66(2): 319-326.

49. de Lamballerie X, Boisson V, Reynier JC, Enault S, Charrel RN, et al. (2008) Vector-borne and zoonotic diseases. Infect Disord Drug Targets 8: 837-840.

50. Mirolo M, Fabbri M, Sironi M, Vecchi A, Guglielmotti A, et al. (2008) Impact of the anti-inflammatory agent bindarit on the chemokinome: selective inhibition of the monocyte chemotactic proteins. Eur Cytokine Netw 19(3): 119-122.

51. Zoja C, Corna D, Benedetti G, Morigi M, Donadelli R, et al. (1998) Bindarit retards renal disease and prolongs survival in murine lupus autoimmune disease. Kidney Int 53(3): 726-734.

52. Chen W, Foo SS, Taylor A, Lulla A, Merits A, et al. (2015) Bindarit, an inhibitor of monocyte 
chemotactic protein synthesis, protects against bone loss induced by chikungunya virus infection. J Virol 89(1): 581-593.

53. Poo YS, Nakaya H, Gardner J, Larcher T, Schroder WA, et al. (2014) CCR2 deficiency promotes exacerbated chronic erosive neutrophil-dominated Chikungunya virus arthritis. J Virol 88(12): 6862-6872.

54. Parashar D, Paingankar MS, Kumar S, Gokhale MD, Sudeep AB, et al. (2013) Administration of E2 and NS1 siRNAs inhibit Chikungunya virus replication in vitro and protects mice infected with the virus. PloS Negl Trop Dis 7(9): e2405.

55. Lam S, Chen KC, Ng MM, Chu JJH (2012) Expression of plasmid-based shRNA against the E1 and nsP1 genes effectively silenced chikungunya virus replication. PLoS One 7(10): e46396.

56. Mahauad-Fernandez WD, Jones PH, Okeoma CM (2014) Critical role for bone marrow stromal antigen 2 in acute Chikungunya virus infection. J Gen Virol 95 (Pt 11): 2450-2461.

57. Goupil BA, Mores CN (2016) A review of Chikungunya virus-induced arthralgia: Clinical manifestations, therapeutics, and pathogenesis. Open Rheumatol J 10: 129-140.

58. Mills M, Estes MK (2016) Physiologically relevant human tissue models for infectious diseases. Drug Discov Today 21(9): 1540-1552.

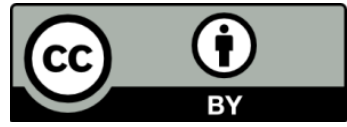

